\section{Planting Depth Effect on Emergence and Morphology of Buffalograss Seedlings}

\author{
Neil L. Heckman ${ }^{1}$, Garald L. Horst ${ }^{2}$, and Roch E. Gaussoin ${ }^{3}$ \\ Department of Agronomy and Horticulture, University of Nebraska-Lincoln, \\ Lincoln, NE 68583-0724 \\ Additional index words. Buchloë dactyloides, coleoptile, establishment, subcoleoptile internode
}

\begin{abstract}
Buffalograss [Buchloë dactyloides (Nutt.) Engelm.] is a warm-season perennial grass native to the North American Great Plains region and has been used as a lowmaintenance turfgrass. Turf-type buffalograsses are available and are commonly used on nonirrigated land. Our objectives were to determine the deepest planting depth of burrs that would allow acceptable emergence, and to evaluate planting depth effects on buffalograss seedling morphology. Two greenhouse experiments were conducted in Fall 2000. Experimental design was a randomized complete block with 4 replications and a 3 (cultivar) $\times 6$ (planting depth) factorial treatment arrangement. Results showed that buffalograss emergence decreased as planting depth increased. All cultivars had $<10 \%$ total emergence at planting depths $>50 \mathrm{~mm}$. Emergence rate indices were greatest when planting depth was $13 \mathrm{~mm}$ and were significantly lower at planting depths of 51 and $76 \mathrm{~mm}$. Average coleoptile length was $11 \mathrm{~mm}$. Coleoptile length was similar between all planting depths except for the $13 \mathrm{~mm}$ depth which resulted in 9-mm-long coleoptile. Subcoleoptile internode length increased with planting depth up to $38 \mathrm{~mm}$. Planting depths deeper than $38 \mathrm{~mm}$ did not significantly increase subcoleoptile internode length.
\end{abstract}

Buffalograss is a warm-season grass native to the North American Great Plains region (Wenger, 1943). Recent water resource concerns have made buffalograss a candidate for turfgrass use. It can be established using sod, plugs, or seed. Many people choose seeding because it has the lowest initial cost for the consumer (Fry, 1995). Establishment by seed is difficult due to weed interference (Falkenberg and Butler, 1981; Wenger, 1943). Buffalograss seeds are encapsulated in burrs, which contain from one to five seeds (Quinn and Engel, 1986). Burrs contain an inhibitory oil, which reduces germination (Ahring and Todd, 1977). Germination is improved when the burr is removed (Riordan et al., 1997), however, this is not economically feasible. Current commercial treatment of burrs with $\mathrm{KNO}_{3}$ can increase germination of seeds from $10 \%$ to $80 \%$, which is still lower than other turfgrasses (Riordan et al., 1997).

Time of year for planting must also be considered when establishing buffalograss. Optimal date of planting is April to May in Kansas (Fry et al., 1993). Best buffalograss establishment in Colorado was when it was seeded in late May (Falkenberg and Butler, 1981). Frank et al. (1998) determined best buffalograss establishment was from late April to June in Nebraska and late April to July in Utah. This corresponds with timely rainfall in

Received for publication 14 May 2001. Accepted for publication 7 Oct. 2001. University of NebraskaLincoln, Agricultural Research Division journal series number 13349. We would like to thank Jeff R. L'Heureux for assistance throughout this research. ${ }^{1}$ Graduate Research Assistant. E-mail address: nheckman@unlserve.unl.edu.

${ }^{2}$ Professor

${ }^{3}$ Associate Professor. these regions along with adequate growth tem-

Warm-season grass stand establishment is also difficult because of slower adventitious root development compared to cool-season grasses (Newman and Moser, 1988b). Hyder et al. (1971) reported that blue grama [Bouteloua gracilis (H.B.K.) Lag ex Stued.] has a subcoleoptile internode elongation which places the seedling crown near the soil surface and deeply planted seedlings are still susceptible to desiccation. Therefore, a relatively long period of moist soil is necessary to develop an adequate root system in many warmseason grasses. The soil surface can quickly dry out in nonirrigated areas. Since buffalograss is commonly used as a turfgrass on nonirrigated land, seedlings arising from burrs at the soil surface can also easily desiccate. Warm-season grasses can generally be planted deeper than cool-season grasses because of greater subcoleoptile internode elongation (Newman and Moser, 1988b). Hudspeth and Taylor (1961) showed that switchgrass (Panicum virgatum $\mathrm{L}$.) had a higher probability of emerging under lower moisture contents at 50- to 75mm planting depths than at shallower planting depths. Subcoleoptile internode length is highly correlated with planting depth in warm-season grasses, however, coleoptile length was only influenced by planting depth in Indiangrass [Sorghastrum nutans (L.) Nash] (Newman and Moser, 1988a). Similar results were found with side-oats grama [Bouteloua curtipendula (Michx.) Torr.], blue panic (Panicum antidotale Retz.), and atherstone lovegrass (Eragrostis lehmanniana Ness $\times$ E. tricophora Coss. \& Dur.) (Roundy et al., 1993).

The morphology of warm-season grass seedlings can vary with planting depth, but peratures. this is not considered a measure of seedling vigor. Seedlings in a stand emerging near the same time and close to the planting date have greater vigor than seedlings emerging over a longer period of time and longer after the planting date. This measurement is called the emergence rate index and was first documented by Evetts and Burnside (1973). However, to fully evaluate a seedling population, both total emergence and seedling vigor must be considered in combination.

Even with greater internode elongation in warm-season grasses, emergence decreases with planting depth (Newman and Moser, 1988a). The planting depth recommendation for buffalograsses is $\leq 13 \mathrm{~mm}$ (Wheeler, 1950). However, in nonirrigated soil, deeper planting may reduce seedling desiccation; this has not been evaluated. Effects of planting depth may also vary with improved turf-type cultivars of buffalograss compared to older forage type cultivars. Our objectives were to determine the deepest planting depth that would allow acceptable emergence and to evaluate the planting depth effects on three buffalograss cultivar seedling morphology and emergence under well-watered conditions.

\section{Materials and Methods}

'Sharp's Improved', 'Cody', and 'Tatanka' buffalograss burrs were planted at six depths in two greenhouse experiments. These cultivars were selected to evaluate differences between one of the older turf-type buffalograsses in 'Sharp's Improved' and two newer releases. 'Sharp's Improved' burrs were supplied by Sharp Brothers Seed Co., Healy, Kans., 'Cody' burrs were supplied by Stock Seed Farms, Inc., Murdock, Nebr., and 'Tatanka' burrs were supplied by Arrow Seed Co., Broken Bow, Nebr. The suppliers primed all burrs with $\mathrm{KNO}_{3}$. Germination for each cultivar was evaluated by placing 25 burrs on a moistened blotter paper contained in plastic plates and replicated four times. Plates were covered and placed in a germination chamber that had 16$\mathrm{h}$ light and 8-h dark cycle with a corresponding 30 and $20{ }^{\circ} \mathrm{C}$ temperature cycle. The number of germinated seeds was determined at the end of a 21-d period and pure live burrs was determined by the percent of burrs that had any germinated seeds.

Greenhouse temperatures ranged from 20 to $30^{\circ} \mathrm{C}$ and 14 -h supplemental lighting from metal halide lamps with an average photosynthetic photon flux $(P P F)$ of $300 \mu \mathrm{mol} \cdot \mathrm{s}^{-1} \cdot \mathrm{m}^{-2}$ was supplied. Plastic pots $(15 \mathrm{~cm}$ in diameter and $25 \mathrm{~cm}$ deep) were filled with medium grade sand. Pots were seeded on 29 Sept. 2000 , with 25 burrs of a single cultivar at 13 , $25,38,45,64$, and $76 \mathrm{~mm}$ and placed in the greenhouse. Burrs were placed in the sand using a forceps marked with each planting depth to insure proper seeding depth. Irrigation was initially supplied until the sand was saturated, and subsequent daily saturation of the sand provided adequate moisture for germination.

Emergence was evaluated daily and emergence rate indices were calculated by using the 
following formula modified from Evetts and Burnside (1973):

Emergence rate index $=$

$$
\frac{\mathrm{E}_{1} / \mathrm{T}_{1}+\mathrm{E}_{2} / \mathrm{T}_{2}+\ldots+\mathrm{E}_{\mathrm{n}} / \mathrm{T}_{\mathrm{n}}}{\% \mathrm{E}}
$$

where $\mathrm{E}_{1}=$ number emerged at first count $\mathrm{T}_{1}$;

$\mathrm{E}_{2}=$ number emerged at second count

$\mathrm{T}_{2}$ minus $\mathrm{E}_{1}$;

$\mathrm{E}_{\mathrm{n}}=$ number emerged at final count $\mathrm{T}_{\mathrm{n}}$ minus prior count;

$\mathrm{T}_{1}=$ days from emergence of first seedling of experiment to first count;

$\mathrm{T}_{2}=$ days from emergence of first seedling of experiment to second count; $\mathrm{T}_{\mathrm{n}}=$ days from emergence of first seedling of experiment to final count; $\% \mathrm{E}=$ total emergence percentage obtained.

Total emergence was determined $21 \mathrm{~d}$ after planting (DAP). A burr was considered to have emerged if any shoots from a burr reached the sand surface. Since the number of individual seeds was unable to be predetermined because of variability within burrs, total plant numbers were not used.

Five seedlings from each treatment were carefully excavated and the sand was washed off 21 DAP. Plants were stored at $5{ }^{\circ} \mathrm{C}$ in plastic bags and root morphology was examined within $7 \mathrm{~d}$ after excavation. Coleoptile and subcoleoptile internode lengths, as defined by Newman and Moser (1988a), were measured under a dissecting microscope.

A second greenhouse experiment was also conducted. Burrs were planted on 27 Oct. 2000. All conditions were identical to the first experiment.

Experimental design was a randomized complete block with four replications and a 3 (cultivar) $\times 6$ (planting depth) factorial treatment arrangement. Hartley's $F$-max test (Hartley, 1950) was used to determine heterogeneity of variance between experiments. Analysis of variance (ANOVA) was used to detect treatment differences and Fisher's Protected LSD was used to separate means.

\section{Results and Discussion}

Heterogeneity of variance was not significantly different between experiments. Therefore, data from both experiments were combined for analysis.

Total emergence was expressed on a pure live burr basis using germination data. Germination was $85 \%, 81 \%$, and $73 \%$ for 'Cody', 'Tatanka', and 'Sharp's Improved', respectively. A cultivar $\times$ planting depth interaction occurred for total seedling emergence (Table 1). Buffalograss emergence decreased with planting depth (Table 2). Emergence was $>20 \%$ for all cultivars at planting depths of $\leq 25 \mathrm{~mm}$. At depths $>25 \mathrm{~mm}$, one or more cultivars had $<10 \%$ emergence. Buffalograss typically has a lower germination percentage than other turfgrasses (Riordan et al., 1997). However, even with expected low emergence of seeded buffalograss, $<20 \%$ is commercially unacceptable.

Table 1. ANOVA table for the effect of planting depth on three cultivars of buffalograss.

\begin{tabular}{lcccc}
\hline \hline Source of variation & Total emergence & ERI $^{\mathrm{z}}$ & Subcoleoptile length & Coleoptile length \\
\hline Cultivar & $*$ & $*$ & NS & NS \\
Planting depth & $* *$ & $* *$ & $* *$ & $*$ \\
Cultivar $\times$ planting depth & $*$ & NS & NS & NS \\
\hline
\end{tabular}

${ }^{2}$ ERI, emergence rate indices.

ss, *,** Nonsignificant and significant at $P \leq 0.05$ and 0.01 , respectively.

Table 2. Percent emergence, emergence rate indices, and subcoleoptile and coleoptile lengths 21 DAP of three cultivars of buffalograss seedlings planted at six depths.

\begin{tabular}{|c|c|c|c|c|c|c|}
\hline \multirow[b]{2}{*}{$\begin{array}{l}\text { Planting } \\
\text { depth }(\mathrm{mm})\end{array}$} & \multicolumn{3}{|c|}{ Total emergence $(\%)$} & \multirow[b]{2}{*}{$\mathrm{ERI}^{\mathrm{z}}$} & \multirow[b]{2}{*}{$\begin{array}{l}\text { Subcoleoptile } \\
\text { length }(\mathrm{mm})\end{array}$} & \multirow[b]{2}{*}{$\begin{array}{c}\text { Coleoptile } \\
\text { length }(\mathrm{mm})\end{array}$} \\
\hline & Cody & $\begin{array}{c}\text { Sharp's } \\
\text { Improved }\end{array}$ & Tatanka & & & \\
\hline 13 & 68.9 & 51.0 & 42.6 & 0.32 & 5.6 & 8.7 \\
\hline 25 & 57.1 & 40.8 & 21.5 & 0.23 & 12.6 & 11.1 \\
\hline 38 & 37.4 & 22.7 & 6.3 & 0.18 & 19.8 & 11.8 \\
\hline 45 & 7.0 & 7.3 & 6.4 & 0.17 & 20.9 & 13.4 \\
\hline 64 & 5.2 & 10.2 & 1.2 & 0.19 & 22.4 & 12.5 \\
\hline 76 & 1.0 & 6.9 & 2.8 & 0.22 & 25.7 & 11.5 \\
\hline $\mathrm{LSD}_{0.05}$ & 2.3 & 2.2 & 3.6 & 0.05 & 2.0 & 2.8 \\
\hline
\end{tabular}

${ }^{\mathrm{z} E R I}=$ emergence rate indices.

No cultivar $\times$ planting depth interaction was observed for the emergence rate index (Table 1). Therefore, data were averaged across cultivars. Emergence rate indices were similar among planting depths $\geq 25 \mathrm{~mm}$ (Table 2). Emergence rate indices were significantly higher for seeds planted at $13 \mathrm{~mm}$, and these seedlings have the potential for greatest vigor. Cultivar differences in average emergence rate indices were detected with 'Sharp's Improved' having a higher index than either 'Cody' or 'Tatanka' (data not shown).

Seedling morphology was also affected by planting depth. No cultivar $\times$ planting depth interactions occurred for either coleoptile or subcoleoptile internode length and data were averaged across cultivars (Table 1). Coleoptile length was consistent over planting depth except for the 13-mm planting depth (Table 2). The 13-mm planting depth had a mean coleoptile length of $8.7 \mathrm{~mm}$ while other depths had a 12.1-mm mean length. These results are consistent with Newman and Moser (1988a), who showed that coleoptile length of warm-season forage grasses was not highly affected by planting depth.

Subcoleoptile internode length increased from 5.6 to $19.8 \mathrm{~mm}$ as planting depth increased from 13 to $38 \mathrm{~mm}$ (Table 2). Subcoleoptile internode elongation was not significantly different from each other at plant depths $\geq 25 \mathrm{~mm}$. This relationship was similar to that found with other warm-season grasses (Newman and Moser, 1988a).

Initial establishment costs of buffalograss can be reduced by using seeded-type cultivars rather than sod or plugs. Since buffalograss is a species used to conserve water, it is often planted in areas receiving no irrigation. The recommended buffalograss planting depth is $13 \mathrm{~mm}$ or less (Wheeler, 1950). In arid regions, seedlings may germinate and desiccate when planted at shallow depths. Switchgrass was shown to have a higher probability of emerging under lower moisture contents at depths of 50 to $75 \mathrm{~mm}$ than shallower planting depths (Hudspeth and Taylor, 1961). These data show that buffalograss planted at either 13 or $25 \mathrm{~mm}$ had significantly greater emer- gence than at deeper planting depths. These depths also had the best emergence rate indices. Planting depth affected seedling morphology as subcoleoptile internode elongation increased with depth of planting. Some plants were able to emerge at 76-mm planting depths, however, emergence was much less than at the shallower depths. Therefore, we conclude that buffalograss planted under irrigated conditions would have better emergence at a $13-\mathrm{mm}$ planting depth than deeper depths.

\section{Literature Cited}

Ahring, R.M. and G.W. Todd. 1977. The bur enclosure of the caryopses of buffalograss as a factor affecting germination. Agron. J. 69:15-17.

Evetts, L.L. and O.C. Burnside. 1973. Early root and shoot development of nine plant species. Weed Sci. 21:289291.

Falkenberg, D.A. and J.D. Butler. 1981. Establishment of quality Buchloë dactyloides turf. Proc. Intl. Turfgrass Res. Soc. 4:105-111.

Frank, K.W., R.E. Gaussoin, T.P. Riordan, andE.D. Miltner. 1998. Date of planting effects on seeded turf-type buffalograss. Crop Sci. 38:1210-1213.

Fry, J., W. Upham, and L. Leuthold. 1993. Seeding month and seed soaking affect buffalograss establishment. HortScience 28:902-903.

Fry, J.D. 1995. Establishing buffalograss. Golf Course Mgt. 63:58-60.

Hartley, H.O. 1950. The maximum $F$-ratio as a short-cut test for heterogeneity of variance. Biometrika. 37:308-312.

Hudspeth, E.B. and H.M. Taylor. 1961. Factors affecting seedling emergence of 'Blackwell' switchgrass. Agron. J. 53:331-335.

Hyder, D.N., A.C. Everson, and R.E. Bement. 1971. Seedling morphology and seeding failures with blue grama. J. Range Mgt. 24:287-292.

Newman, P.R. and L.E. Moser. 1988a. Grass seedling emergence, morphology, and establishment as affected by planting depth. Agron. J. 80:383-387.

Newman, P.R. and L.E. Moser. 1988b. Seedling development and morphology of cool-season and warm-season forage grasses. Crop Sci. 28:148-151.

Quinn, J.A. and J.L. Engel. 1986. Life-history strategies and sex ratios for a cultivar and a wild population of Buchlö̈ dactyloides (Gramineae). Amer. J. Bot 73:874-881.

Riordan, T.P., P.G. Johnson, R.E. Gaussoin, and J.F. Svoboda. 1997. Seedling germination and establishment of Buchloë dactyloides caryopses vs. burrs. Intl. Turfgrass Soc. Res. J. 8:749-756.

Roundy, B.A, V.K. Winkel, J.R. Cox, A.K. Dobrenz, and H. Tewolde. 1993. Sowing depth and soil water effects on seedling emergence and root morphology of three warm-season grasses. Agron. J. 85:975-982.

Wenger, L.E. 1943. Buffalo grass. Kans. Agr. Ext. Sta. Bul. 321.

Wheeler, W.A. 1950. Forage and pasture crops. D. Van Nostrand Co., New York. 